\title{
Brexit: The Consequences in the EU Integration Process of the Western Balkans
}

\section{Gledina Mecka}

\author{
PhD Candidate, Albanian National Bar Association, Tirana; Email: jurist.gledina@gmail.com
}

\section{Doi:10.5901/mjss.2016.v7n6p271}

\begin{abstract}
With the big purpose of being integrated and becoming EU member states, the Western Balkan countries started and urged reform packages which include national political and economic reforms and regional reforms. There has been significant progress, accompanied also with difficulties. But besides all the difficulties, currently EU is also facing a major political issue which is the BE leaving by the United Kingdom or the so called "Brexit". Does the Brexit consequence affect the integration towards the EU of the Balkan aspirants? There are opinions that regardless of the consequence, the issue of further enlargement in the Balkans will be left behind and will be treated as a matter of secondary importance. After Croatia's accession in 2013, Albania, Montenegro, Serbia, Bosnia-Herzegovina, Kosovo, and Macedonia are negotiating to become candidate countries or member countries. Is this enlargement of the Western Balkans going to be followed by the same intensity and surveillance from the EU? Is the Western Balkans losing a primary advocate for expansion? Will the Brexit expend the EU's policies and thus reduce the EU interest in enlargement? This paper's aim is to examine if and how Brexit will harm the EU's impact on the development of democracy in the Western Balkans and further more the EU membership.
\end{abstract}

Keywords: Brexit, political issue, primary advocate, Western Balkans, EU enlargement.

\section{Introduction}

EU enlargement process started with the accession of new member states began with Inner Six, which in 1958 founded the EEC ${ }^{1}$. Since this time, EU membership has expanded to twenty-eight. The latest member state is Croatia, which became part of the EU in July 2013.

Widening the EU membership has encouraged economic systems and democracy in countries emerging from dictatorship. That is why this process is so important to the Western Balkans as countries with weak democratic systems.

The 2003 European Council Summit in Thessaloniki decided the integration of the Western Balkans to be high priority of EU enlargement. The enlargement is a process which has accepted a new member state in 2013 and has continued to enhance the efforts of these countries to fulfill the Copenhagen Criteria. Since the EU foundation, the organization has accepted 28 member states.

The United Kingdom applied to be a member of the Communities and joined the EU in 1973. In 1975 Britain held a referendum on its membership but $66 \%$ voted to stay in the EU. Britain has always been skeptical and not fully involved within the EU. Signing the Maastricht Treaty in 1991 with the purpose to create a single European currency, Britain decided not to participate in a single currency. So, Britain was part of the EU but did not want to have a single currency, until June 2016 where a referendum was held and the UK voted to withdraw from the EU (Brexit). This is the first case where a member state leaves the EU. Is the EU unprepared to manage this? Which will the effects be for EU and particularly for the candidate states and the enlargement process?

\section{Brexit. What is it?}

"Britain exit" or "Brexit" refers to the June 23 referendum by British voters who voted 52 to $48 \%$ in favor of quitting the European Union. It is a fact that Britain's people want to leave the UE and it is also a fact that this is going to happen. This is the major political change since the fall of the Berlin Wall. It is for sure that Brexit will affect the UK and EU policies and economies, the candidate countries and even global markets.

The Brexit vote has resulted in considerable uncertainty that makes any prediction difficult. Yet it is this uncertainty itself that will be an important feature of Europe over the coming years and will influence policy making and bears considerable risks. The consequence of the Brexit is both structural, which means the ability of the EU to act and integrate, which means new members and normative the ability of the EU to promote a particular type of democratic, consensus-oriented system of government. ${ }^{2}$

\footnotetext{
1 European Economic Community

${ }^{2}$ http://www.suedosteuropa.uni-graz.at//biepag/node/224
} 


\section{The Western Balkans and Brexit Impact}

There are presented by different analysts' scenarios for how Brexit might affect the Western Balkans. All the scenarios highlight the considerable risks that Brexit holds for the Western Balkans.

With the EU self-absorbed and diminished, focused elsewhere for years to come, the countries of the region can no longer rely on the EU to promote reform and the consolidation of democracy. With the transformative appeal of the EU largely gone and its ability to act reduced, others will fill the void. Social movements, media and independent institutions will have fewer external allies to rely on. This could strengthen domestic engines of change, yet might also dampen them, if these movements lack normative models to appeal to beyond their borders. To counter this negative trend, key EU members, in particular Germany, but also the United States, might have to form coalitions to continue support for democratic change in the Western Balkans. Supporters of democracy will need to stop relying on EU accession as the answer. Without the risk of armed conflict, the Western Balkans are likely to remain a low priority, yet the seeping authoritarianism is not just a risk for the region, but part of a wider European malaise that cannot be ignored any longer. ${ }^{3}$

On the other hand, Balkan leaders wanted one single result of the British referendum: To not leave the EU. This means that the Balkan leaders are looking to the EU as a destination and integration of their political systems. Thus, an EU committed and really focused on these tasks, is therefore important to encourage the integration and membership processes.

The commitment to implement the reforms was already in doubt, but joining the EU has been a priority only because of bonuses by Western governments and the requirements of a large part of the voters. Serbia and Montenegro are in accession negotiations, Albania and Macedonia are candidate countries, and meanwhile Bosnia and Herzegovina has recently submitted its application for EU membership. While Kosovo has recently concluded a Stabilization and Association Agreement

According to the professor of the University of Graz "As a technical process, the enlargement has lost much of its political momentum. The countries of the Western Balkans are losing a key advocate of enlargement. As many member states have become critical towards enlargement, the UK has promoted both enlargement and reform in the region vigorously. Together with Germany, it has been the only large EU country to drive EU policy making the region in the past decade. Now this advocate of enlargement will disappear." 4

The UK can promote reforms and the EU entrance following the United States instance, which has sustained the expansion of the EU and the EU policy in the SEE region. The political consideration and the bureaucratic tools of the EU will concentrate on the administration of the relationship between the UK and EU. This relationship will imbibe the EU attention. The expansion and reforms in the Western Balkans in this way will become second hand importance from the EU perspective. Even if Britain try to remain united and continue to have its influence on the EU, the withdrawal of membership from the EU will result with reduced impact on the Western reforms. This means that Brexit will negatively affect the process of enlargement of the EU and the progress of democracy in the Western Balkans. UK leaving the European Union will more likely have major consequences for the UK, but also for the EU and for the Western Balkan countries at different stages of becoming UE members. Brexit brings uncertainty and this makes forecasting not easy. If real prospects for membership of these countries disappear, then the regional democracy can experience serious obstacles.

There is, however, one major difference. The UK has left the European Union, but not Europe. ${ }^{5}$

The leaders of the region have expressed in unison, with a few exceptions, their determination to continue following the European path, while acknowledging the impact of the UK referendum.

The President of the Council of Ministers of Bosnia and Herzegovina, Denis Zvizdić, has expressed his willingness to continue on the current path, seeking to minimize the potential impact of Brexit: "The UK has made a fundamental contribution, together with Germany, to boost our country's proximity to the EU. Despite having lost a vote in favor, we have not lost the support of an ally who will continue to pressure in favor of our European path. Our priority remains unchanged, and it is the integration within the European Union. Many will wonder why some countries want to join the EU now that one of its most important members is to leave it. The reason is that 80 percent of $\mathrm{BiH}$ citizens support this choice. "6

As did Zvizdić, the leaders of Albania, Macedonia and Montenegro also reaffirmed their commitment to Europe.

\footnotetext{
${ }^{3}$ https://europeanwesternbalkans.com/2016/06/26/ever-farther-union-balkans-and-the-brexit/

${ }^{4}$ http://www.suedosteuropa.uni-graz.at/biepag/node/224

${ }^{5} \mathrm{http} / / / \mathrm{blogs./se.ac.uk/europpblog/2016/06/24/reaction-to-brexit-around-europe-how-the-result-affects-the-balkans/}$

${ }^{6}$ http://www.balcanicaucaso.org/eng/All-the-news/Brexit-the-consequences-for-the-EU-enlargement-172406
} 
Bosnian Serb Prime Minister Zeljka Cvijanovic said aspiring members must accept that joining the EU will be delayed by Brexit "because it will take several years for the EU to consolidate and carry out the reforms it should have done years ago to prevent such things from happening". Analyst Igor Gavran said Bosnia could expect political fallout from Brexit "because Britain was one of the countries that most openly supported the integration of Bosnia into the EU". In Kosovo, European Integration Minister Bekim Collaku said that his country, which seceded from Serbia in 2008, had also lost a strong supporter of its EU bid. "We know the big contribution Great Britain made towards building Kosovo's statehood and it will be difficult for another country to fill this vacuum," he told local media. An Albanian official said his country had learnt that big crises such as the migrant issue, the euro and Greece distracted EU leaders from paying attention to the Balkans. Montenegro's EU negotiator, Andrija Pejovic, was optimistic that membership negotiations could move forward as planned, but acknowledged matters were unclear. "In the coming days we will see what position the EU bodies will take regarding this issue," he said. For Macedonia, nothing has changed post-Brexit. Its EU bid remains blocked by a dispute with Greece over its name, which Athens says should belong only to its own province of Macedonia. ${ }^{7}$

Last Friday, from Vienna, the Enlargement Commissioner Johannes Hahn reassured that the work of the Commission continues: "Much has been achieved in the Balkans in recent years, and there is no reason to leave room to fatigue and frustration after the referendum in the UK". ${ }^{8}$

\section{Conclusions}

In any case Brexit will have a negative impact on the enlargement process. The political consideration and the bureaucratic tools of the EU will concentrate on the administration of the relationship between the UK and EU. This relationship will imbibe the EU attention. The expansion and reforms in the Western Balkans in this way will become second hand importance from the EU perspective. Even if Britain try to remain united and continue to have its influence on the EU, the withdrawal of membership from the EU will result with reduced impact on the Western reforms. This means that Brexit will negatively affect the process of enlargement of the EU and the progress of democracy in the Western Balkans. Whatever happens, the effort required to redefine the relationship between the UK and EU will absorb the attention of Brussels for a time to be determined, diverting energy from the enlargement process. If real prospects for membership of these countries disappear, then the regional democracy can experience serious obstacles. Even before the Brexit referendum, the Western Balkans and the EU enlargement process were not "high priority" of the EU. Taking in consideration the economic crisis in 2007 and 2008, and now the member states leaving the EU, the organization has not been very concerned with enlargement process. The EU will be busy protecting the European structure and its acquirements. In this situation it is hard to visualize the member states to show immediate commitment towards the EU enlargement, moreover as the Western Balkans are economically weak and their democracy systems are not stabilized. On the other hand, despite the fact that many thinks that without the surveillance of the EU on political processes in the Western Balkans, the throwback in democracy and stabilization process will happen, there is an opposite example. Albania has initiated the judicial reform which is the first precondition for opening the negotiation chapters and a key factor for this has been the EU Ambasador Romana Vlahutin. The EU should not abandon the Western Balkans. The regions' dangerously high levels of unemployment (over $25 \%$ ), endemic corruption and weak governance would strengthen the hands of populists and instability could follow. This is not what EU needs. The enlargement process should not be slowed down.

\section{References}

https://europeanwesternbalkans.com/2016/06/26/ever-farther-union-balkans-and-the-brexit/ http://www.suedosteuropa.uni-graz.at/biepag/node/224

http://www.balcanicaucaso.org/eng/All-the-news/Brexit-the-consequences-for-the-EU-enlargement-172406 http://www.spiegel.de/international/europe/opinion-after-brexit-vote-fears-balkan-states-will-be-forgotten-a-1102165.html http://blogs.Ise.ac.uk/europpblog/2016/06/24/reaction-to-brexit-around-europe-how-the-result-affects-the-balkans/

\footnotetext{
7 http://www.reuters.com/article/us-britain-eu-balkans-idUSKCNOZEOR5. (Reporting by Ivana Sekularac, Benet Koleka, Fatos Bytyci, Petar Komnenic, Kole Casule and Maja Zuvela; Editing by Richard Balmforth)

${ }^{8} \mathrm{http}: / / w w w . b a l c a n i c a u c a s o . o r g / e n g / A l l-t h e-n e w s / B r e x i t-t h e-c o n s e q u e n c e s-f o r-t h e-E U-e n l a r g e m e n t-172406$
} 
ISSN 2039-2117 (online)

ISSN 2039-9340 (print)
Mediterranean Journal of Social Sciences MCSER Publishing, Rome-Italy
Vol 7 No 6 November 2016 